Головач Анастасія Ігорівна, студентка Навчально-науковий інститут права Сумського державного університету. 40001, м. Суми, вул. Петропавлівська, 57

Глущенко Наталія Володимирівна, доктор філософії зі спеціальності «Право», асистент кафедри адміністративного, господарського права та фінансово-економічної безпеки Навчально-наукового інституту права Сумського державного університету. 40001, м. Суми, вул. Петропавлівська, 57, https://orcid.org/0000-0002-4104-7791

\title{
ЗАХИСТ ПРАВ ІНТЕЛЕКТУАЛЬНОЇ ВЛАСНОСТІ КОРИСТУВАЧА ПЕРСОНАЛЬНОЇ СТОРІНКИ У СОЩАЛЬНИХ МЕРЕЖАХ
}

Анотація. У статті розглянуті специфіка та проблеми захисту авторського права на об'єкти, розміщені в соціальних мережах. Досліджено можливості захисту авторського права на об'єкти, розміщені на просторах мережі інтернет загалом та в окремих випадках. Застосування законодавства, що регулює правовідносини у сфері інтелектуальної власності на практиці, демонструє яскраві приклади правопорушень та неможливість забезпечення повної безпеки суспільства. Розглянуто ряд неточностей, які містить чинне законодавство відносно регулювання вищезазначених правовідносин. Задля профілактики порушень у сфері авторського права існує дві форми захисту: юрисдикційна (коли особа звертається за захистом до державного органу чи установи, яка має відповідну компетенцію) та неюрисдикційна (коли особа, чиї права були порушені, самостійно вирішує проблему, без звернення у відповідні органи. Оскільки українське законодавство має певні прогалини у сфері інтелектуальної власності, це значно ускладнює процес його регулювання. Таким чином, велика кількість осіб, що стали жертвами порушення авторського права, віддають перевагу неюрисдикційній формі захисту. Не зважаючи на популярність соціальних мереж, досі немає чіткого алгоритму регулювання відносин, що стосуються захисту прав інтелектуальної власності в цих мережах. Не так багато можна знайти прикладів судових справ, що стосуються порушень авторського права в мережі Інтернет, а що стосується соціальних мереж - такі судові практики наразі в Україні взагалі відсутні. Важливо зазначити, що соціальні мережі не несуть пряму відповідальність за контент, який там розміщено. Оскільки дії відбуваються в рамках віртуального соціуму, то й санкції за порушення теж зазвичай віртуальні. Захисту прав інтелектуальної власності в соціальних мережах в судовому порядку не варто швидко чекати. Проте, в кожній спільноті існують певні Правила користувача, 
які мають на меті захистити авторські права користувачів. Зроблено висновки, що інтелектуальна власність в соціальних мережах має охоронятися не лише Правилами користувача, але й більш досконалими законодавчими документами. Це має удосконалити систему розв'язання спорів у сфері інтелектуальної власності на законодавчому рівні. Це сприятиме зменшенню правопорушень в даній сфері.

Ключові слова: авторське право, соціальні мережі, правила користувача, відповідальність за правопорушення в Інтеренеті.

Holovach Anastasiia Ihorivna, student of the Academic and Research Institute of Law of Sumy State University. 40001, Sumy, street Petropavlivska, 57

Hlushchenko Nataliia Volodymyrivna, PhD in Law, Assistant Lecturer of the Administrative, Economic Law and Financial and Economic Security department of the Academic and Research Institute of Law of Sumy State University. 40001, Sumy, Str. Petropavlivska, 57, https://orcid.org/0000-0002-4104-7791

\section{PROTECTION OF INTELLECTUAL PROPERTY RIGHTS OF THE PERSONAL PAGE IN SOCIAL NETWORKS}

Abstract. The article discusses the specifics and problems of copyright protection for objects posted on social networks. Possibilities of copyright protection for objects, posted on the Internet in general and in individual cases have been studied. The application of legislation regulating legal relations in the field of intellectual property in practice demonstrates striking examples of offenses and the inability to ensure the total security of society. A number of inaccuracies in the current legislation regarding the regulation of the above-mentioned legal relations are considered. There are two forms of protection for the prevention of copyright infringements: jurisdictional (when a person applies for protection to a state body or institution with relevant competence) and non-jurisdictional (when the person whose rights have been infringed solves the problem independently without recourse to the relevant authorities. As Ukrainian legislation has specific gaps in the field of intellectual property, it significantly complicates the process of its rule. Thus, many victims of copyright infringement prefer a non-jurisdictional form of protection. Despite the popularity of social networks, there is still no clear algorithm for regulating the protection of intellectual property rights in these networks. There are not many examples of lawsuits related to copyright infringements on the Internet. As far as social networks are concerned, such case law is currently non-existent in Ukraine. It is important to note that social networks are not directly responsible for the content posted there. Because actions take place within a virtual society, sanctions for violations are also usually virtual. Protection of intellectual property 
rights on social networks in court should not be expected quickly. However, certain User Guidelines in each community aim to protect users' copyrights. It is concluded that intellectual property in social networks should be protected not only by the User's Rules but also by better legal documents. It should improve the intellectual property dispute resolution system at the legislative level. It will help reduce offenses in this area.

Keywords: copyright, social networks, user rules, liability for offenses on the Internet

Постановка проблеми. Розвиток сучасної держави важко уявити без використання сучасних технологій. Вагому роль у розвитку технологій займає мережа Інтернет, яка орієнтована на врахування інтересів всіх категорій людей. Зараз кожен має вільний доступ до інформації розміщеної в мережі, може нею користуватися, зберігати, накопичувати та розповсюджувати.

Значне місце в нашому сьогоденні посідають соціальні мережі. Там ми проводимо свій вільний час, спілкуємось, обмінюємось інформацією та працюємо. Як і кожна сфера нашого життя, соціальні мережі потребують законодавчого регулювання, особливо у сфері захисту авторського права.

Наразі ми стикаємось з відсутністю можливості регулювання відносин в соціальних мережах відповідно до національного законодавства. Соціальні мережі не несуть відповідальність за розміщуваний контент. Таким чином, майже неможливо довести вину за порушення кимось авторського права. Наразі, відносини в соціальних мережах регулюються лише згідно Правил користувача, які адаптовані під кожну соціальну мережу.

Таким чином, кожен користувач самостійно несе відповідальність за свої діï. Єдиною інстанцією до якої можна звернутися у випадку порушення авторського права в соціальній мережі є адміністрація даної мережі. Немає чіткого переліку санкції за такі правопорушення, найдієвішим способом вирішення конфліктів $\epsilon$ або самостійне 3'ясування між порушником та постраждалим або санкції з боку адміністрації у вигляді попереджень, видалення частки контенту чи повного заблокування аккаунту.

Актуальність даного дослідження полягає в тому, що застосування законодавства щодо відповідальності у сфері інтелектуальної власності на практиці демонструє нам недосконалість системи, що призводить до порушення прав та утворення певних перешкод при забезпеченні безпеки особи та суспільства у сфері інтелектуальної власності.

Аналіз останніх досліджень і публікацій. Було проведено багато досліджень, що стосуються даної теми. Визначних здобутків в дослідженні даної теми досягли такі науковці: Аврамова О.С., Бойченко А., Крупчан О.О., Кетрарь А.А., Пастухов О. М., Крупчан О.О., Римаренко I.В., Савич С.С., О.С. Брель, О.О. Кулініч, О.В. Кохановська. 


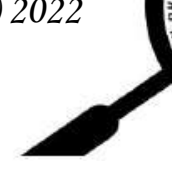

Метою даної статті є дослідження специфіки та проблем застосування регулювання правовідносин у сфері авторського права в соціальних мережах.

Виклад основного матеріалу. Час не стоїть на місці, і стрімкий розвиток сучасних технологій тому доказ. Ще 20 років назад суспільство лише починало знайомитись 3 мобільним зв'язком та електронною поштою, а сьогодні нам важко уявити своє життя без мережі Інтернет. Щодня ми звертаємось до неї на кожному кроці - для роботи, для навчання, у побуті або просто для розваг тощо. Дослідження, які здійснив доктор Мартін Гільберт, з Університету Південної Каліфорнії, показують нам, що сучасна людина за один день отримує в 5 разів більше інформації, ніж це було 30 років тому. I як стверджують вчені - це лише самий початок інформаційної епохи. В майбутньому, кількість даних буде значно збільшуватись.

Майже кожна країна світу авторським правом охороняє твори в галузях літератури, мистецтва та музики. Зазвичай в міжнародних конвенціях та національному законодавстві країн щодо авторського права міститься перелік об'єктів правової охорони, що не є вичерпним. Як правило, там наведено літературні, музичні та аудіовізуальні твори, фотографії, картини, малюнки, ілюстрації, карти, плани, ескізи тощо [1].

Що ж стосується повідомлень про новини дня або повідомлень про поточні події, які зазначені в якості пресінформації, творів фольклору, а також державних документів, символів та знаків, то вони звичайно не охороняються [1].

Вищезазначений перелік творів літературного та художнього характеру досить часто можна зустріти в Інтернеті і всі вони можуть претендувати на захист авторським правом. Проте, лише приналежності до категорії творів, які визначені переліком в законі, може бути недостатньо.

Так, система регулювання питань порушень та захисту авторського права на сьогоднішній день недосконала. Проте, помилково буде зазначити, що в епоху інформаційних досягнень, особа не має жодної можливості на відстоювання таких прав. Насправді ж, існує чимало інструментів для захисту своїх прав після моменту їх порушення.

Існує декілька технічних та правових прийомів для доведення факту порушення розміщень творів в Інтернеті:

1. Агенти - представляють собою комп'ютерні програми, що попередньо запрограмовані на виконання визначених команд. Зазвичай агентів використовують для виявлення в мережі Інтернет контрафактних творів. Дана технологія досить нова та ще знаходиться на етапах розробки та вдосконалення, проте вже є декілька досить потужних наборів засобів пошуку, які використовують повнотекстові пошукові програми. Серед таких програм, можемо зазначити HotBot та Alta Vista.

2. Стеганографія має на меті заховати інформацію, яка міститься у файлах таким чином, що дані, які були приховані, неможливо буде легко знайти. Найпоширенішим способом використання стенографії в Інтернеті $є$ введення 
«водяного знаку». Таке просте «кодування» може слугувати доказом того, що контрафактний примірник твору, було створено власником авторських прав, а не їх порушником [2].

Така технологія дозволяє долучити до файлу з твором не лише знак, але й інформацію про управління правами. За дещо іншого підходу кожній авторизованій копії файлу надається серійний номер, що дає власнику авторських прав змогу відстежити джерело примірників творів, які з'явились в Інтернеті без його згоди [3].

3. Судове переслідування є досить потужним інструментом для реалізації та захисту прав інтелектуальної власності. Звісно, не всі правопорушення стають предметами судового розгляду, проте існування такої загрози $\epsilon$ ефективним стимулом.

Розгляд порушень авторського права в суді дає змогу отримати компенсацію за такі порушення. Окрім цього, судове переслідування $\epsilon$ публічним застереженням інших про наслідки протиправної поведінки. Чимало власників, яким вдавалося здобути успіх у судовому переслідуванні порушників своїх авторських прав на розміщення творів в мережі Інтернет, подбали про те, щоб результати судових процесів стали відомі широкому колу осіб.

У підсумку можемо зазначити, що задля профілактики порушень у сфері авторського права існує дві форми захисту: юрисдикційна (коли особа звертається за захистом до державного органу чи установи, яка має відповідну компетенцію) та неюрисдикційна (коли особа, чиї права були порушені, самостійно вирішує проблему, без звернення у відповідні органи).

Оскільки українське законодавство має певні прогалини у сфері інтелектуальної власності, це значно ускладнює процес його регулювання. Таким чином, велика кількість осіб, що стали жертвами порушення авторського права віддають перевагу неюрисдикційній формі захисту. Не так багато можна знайти прикладів судових справ, що стосуються порушень авторського права в мережі Інтернет, а що стосується соціальних мереж - такі судові практики в Україні взагалі відсутні наразі.

Щодня більшість 3 нас витрачає час на перегляд відео, прослуховування музики та поширення фото в соціальних мережах. За цим величезним напливом інформації люди навіть не встигають задумуватись над тим, що в багатьох випадках користувачі додатків Instagram, Tik-Tok тощо можуть порушувати авторські права або ж ставати жертвами таких правопорушень.

Згідно з дослідженням CMeter, TNS, найпопулярнішими серед українських користувачів Інтернету у вересні 2021 року були соціальні мережі Facebook та Instagram. Досліджуючи розвиток соціальних мереж, до цього списку можна додати таку соціальну мережу, як Tik-Tok. I хоча вона й відсутня в переліку топових позицій, але соціальні дослідження стверджують про стрімкий розвиток та популяризацію даного додатку, особливо серед молодіжної аудиторії. 
Відповідно до статистики, що зазначена на statista.com лідерські позиції займає Facebook. Компанія Facebook заснована в 2004 році Марком Цукенбергом. Спочатку, основним задумом було створення віртуального каталогу з фотографіями та основною інформацією студентів Гарвардського університету. Марк Цукерберг проник у комп'ютерну мережу університету і скопіював фотографії зі всіх студентських посвідчень. Вистачило декількох днів для того, щоб веб-сайт 3 даними однокурсників відвідали майже всі студенти. Адміністрація університету відреагувала швидко - сторінка була закрита за порушення безпеки та права на особисту інформацію, проте правопорушення Цукенбергу пробачили.

I хоча перша версія сайту була створена з явним порушенням авторських прав та прав на особисту інформацію, оскільки були використані дані 3 серверів Гарварду, проте вже за рік компанія набула загального поширення. У 2004 році світ побачив сайт Thefacebook. Спочатку він був доступним лише для студентів Гарварду, незабаром була відкрита реєстрація для всіх студентів Бостону, а потім і для всіх Сполучених Штатів. У 2006 році сайт став доступним усім користувачам інтернету. Наразі, кількість користувачів нараховує приблизно 3 млн облікових записів з усього світу.

За минулий час зовнішній вигляд та наповнення мережі зазнали значних перевтілень. Проте принцип роботи залишився незмінним. Користувачі мережі створюють власні профілі з особистою інформацією, контактними даними, списками захоплень та фотографіями. Також вони мають можливість спілкуватися з друзями персонально чи в групах за інтересами.

У 2010 році світ дізнається про новий додаток Instagram, який заснували Кевін Сістром і Майк Крігер. Мережа була створена для того, щоб люди могли обмінюватися, лайкати та коментувати фотографії. У 2012 році Instagram був куплений компанією Facebook.

За 10 років існування мережі Instagram, вона 3 простого фотообмінника перетворилась на гіганта серед бізнес-платформ, що приносить мільйони користувачам. Зараз Instagram - потужна соціальна система, яка вивела на новий рівень рекламу, оскільки перенесла рекламну модель 3 Facebook та отримала можливість заробляти на розміщенні реклами. Це було важливим кроком при переході від творчості до комерціалізації. Сьогодні - це мережа, яка вивела людей на новий рівень розуміння реклами, фотографії та контенту в цілому. Тут вже важливі не лише фото, але й побудова особистого бренду користувача.

У вересні 2016 року на ринок Китаю виходить додаток Douyin, який запущено фірмою ByteDance. I хоча ця назва менш популярна, проте за нею стоїть нині популярний Tik-Tok. Вiн має досить довгу та насичену історію, починаючи з об'єднання з невеликою музичною платформою.

У 2018 році Tik-Tok став завантажуваним застосунком у світі (близько 104 мільйонів завантажень), який обійшов таких титанів як YouTube, WhatsApp та Instagram. 
У США встановлення TikTok відбувалося частіше, аніж за застосунки компаній Facebook, Instagram, Snapchat i YouTube у значенні денного завантаження 29 вересня 2018 року. Майже через місяць TikTok продовжив розширення на ринку, вийшовши з 30 \% до $42 \%$ ринкових завантаження серед групи застосунків медійних соціальних мереж. [4]

Додаток дозволяє переглядати та знімати музичні відео з можливістю їх редагування одразу в програмі.

Не зважаючи на популярність даних соціальних мереж, досі немає чіткого алгоритму регулювання відносин, що стосуються захисту прав інтелектуальної власності в цих мережах.

На сьогоднішній день неможливо знайти приклади судових справ щодо порушення авторського права саме в соціальних мережах. Така практика більш поширена стосовно веб-сайтів в мережі Інтернет. Так, є встановлена вимога до власників веб-сайтів щодо повідомлення контактних даних для зв'язку з ними. У ч. 7 ст. 52-1 Закону України «Про авторське право і суміжні права» вказується, що заявник у визначених випадках має право звернутися безпосередньо до постачальника послуг хостингу, який надає послуги та (або) ресурси для розміщення відповідного веб-сайту, із заявою про припинення порушення, допущеного власником веб-сайту [5].

Згідно 3 ч. 1 ст. 52-1 Закону України «Про авторське право і суміжні права», що визначає порядок припинення порушень авторського права та (або) суміжних прав з використанням мережі Інтернет, у випадку порушення будьякою особою авторського права та (або) суміжних прав, вчиненого 3 використанням мережі Інтернет, суб'єкт авторського права та (або) суміжних прав має право звернутися до власника веб-сайту та (або) веб-сторінки, на якому (на якій) розміщена або в іншій спосіб використана відповідна електронна (цифрова) інформація, із заявою про припинення порушення. Порядок захисту авторського права та (або) суміжних прав, визначений цією статтею, є позасудовим [5].

Чітким доказом цього $є$ п. 13 Інформаційного листа Вищого господарського суду України «Про деякі питання практики застосування господарськими судами законодавства про інформацію» в якому зазначається: «у разі розміщення інформації в мережі Інтернет у вигляді, доступному для публічного ознайомлення, особа, чиї права та законні інтереси порушені іiі поширенням, може подавати відповідні позовні вимоги до власника веб-сайту, на якому розміщена ця інформація» [6].

В таких випадках легше відслідкувати та зафіксувати правопорушення, оскільки у веб-сайту завжди є зазначений власник, особу якого встановити більш реально, аніж власника сторінки в соціальній мережі.

Зазвичай, кожна соціальна мережа намагається самостійно регулювати ситуацію відповідно до політики у відношенні прав інтелектуальної власності. Розглянемо це на прикладі найбільш популярних нині соціальних мереж: 
Facebook, Instagram ta Tik-Tok.

При створенні облікового запису в цих мережах кожен користувач має підтвердити факт ознайомлення 3 Правилами спільноти та Угодою користувача, що свідчитиме про його згоду на дотримання прав інтелектуальної власності при користуванні мережею.

Загалом, політика інтелектуальної власності в мережах Facebook, Instagram та Tik-Tok керується Законом США «Про захист авторських прав у цифрову епоху» (United States Digital Millennium Copyright Act, DMCA), що зазначено на офіційному сайті довідкового центру.

Основною вимогою є публікація контенту, який користувач створив самостійно, або такого, який він має право поширювати. Знову ж таки, конкретні межі стосовно того, що мається на увазі під «правом поширення» не окреслено. Проте зазначено, що за розміщення та поширення матеріалів, які порушують умови використання, автор може понести відповідальність.

Як зазначено в угоді користувача, яку всі підтверджують при реєстрації у мережі, що користувачі мають право на контроль та визначення рівня доступу до публікацій. Експерти завжди радять контролювати свої налаштування мінімум раз на місяць.

Ви маєте права на інтелектуальну власність (такі як авторські права або торгові марки) щодо будь-якого такого контенту, який ви створюєте і яким ділитеся у Facebook та інших застосовуваних вами Продуктах Компанії Meta. Ніщо в цій Угоді не позбавляє вас прав на власний контент. Ви маєте право вільно ділитися своїм контентом з іншими людьми будь-де.

Однак для надання послуг необхідно, щоб ви дали юридичні дозволи (відомі як «ліцензія») на використання цього контенту.

Зокрема, коли ви публікуєте або завантажуєте контент, який є об'єктом права інтелектуальної власності, ви даєте невиключну ліцензію 3 правом передачі та видачі субліцензій на зберігання, використання, розповсюдження, зміну, запуск, копіювання, публічне виконання або показ, переклад вашого контенту та створення похідних робіт на його основі (відповідно до ваших налаштувань конфіденційності та додатка). Це, наприклад, означає, що, якщо ви ділитеся фото на Facebook, ви дозволяєте зберігати, копіювати і передавати його (з урахуванням ваших налаштувань), наприклад, постачальникам послуг, які підтримують сервіси або інші продукти Meta, які ви використовуєте. Дія цієї ліцензії закінчується, коли контент буде видалено з систем. [7]

Заради захисту своїх користувачів, мережа Facebook залишає за собою право на обмеження доступу до контенту, який порушує порушує дане положення.

Також, адміністрація рекомендує скаржитися на контент та поведінку, яка порушує Ваші права або права спільноти. Таким чином, це виступає єдиним можливим захистом прав на інтелектуальну власність в соціальній мережі.

Загалом, в Instagram виділено 3 категорії авторських прав: 
повідомлення тощо;

аудіо-контент: музичні композиції, мелодії, пісні, голосові

- візуальний контент: фотографії, відео, зображення, відео повідомлення тощо;

- письмовий контент: статті, літературні твори та цитати, матеріали курсів, тексти з інших постів тощо.

Розглядаючи на прикладі, можна дослідити наступну ситуацію. Користувач на своїй персональній сторінці викладає відео, де використовується музика, яка є об'єктом авторського права без дотримання всіх алгоритмів соцмережі (тобто без представлення доказів того, що він має право на використання такого твору). В такому випадку, адміністрація Instagram має право видалити цю публікацію. В разі декількох повторних порушень профіль може бути заблоковано.

Що ж стосується мережі Tik-Tok, то адміністрація має право не лише заблокувати обліковий запис користувача, але й відмовити в можливості створення нового облікового запису на сайті чи у додатку. Також у додатку $є$ можливість виставляти приватний режим для свого аккаунту. Такі міри дозволяють переглядати контент лише обраним користувачам. Разом 3 тим, можна обмежити кількість людей, які можуть коментувати чи надсилати повідомлення.

Особливо варто звернути увагу на такі функції Tik-Tok, як «duet» чи «react». Перша, дозволяє паралельне створення нового відео поруч 3 вже існуючим, а друга - дозволяє помістити нове відео у меншому форматі, який потім можна дивитися на вже записаному відеофайлі.

Насправді, такі ефекти можна назвати ефектом «прихованої камери» нічого протизаконного, лише реакція. На нашу думку, такі ефекти дають ширші можливості для порушення авторських прав. Таким чином, користувачі все одно мають можливість поширювати чужу творчість (інколи без згоди автора) прикриваючи це тим, що виставляють свою реакцію, а вже оригінал відео - це лише доповнення.

Для того, щоб захистити власні авторські права в мережі Instagram, TikTok та якщо їх було порушено, є два основні шляхи вирішення. Можна безпосередньо зв'язатися 3 користувачем, який опублікував вашу інтелектуальну власність. Іншим, більш жорстким рішенням проблеми буде онлайн повідомлення зі скаргою, де зазначений повний перелік претензій. Що важливо - для того, щоб подати скаргу, не обов'язково мати сторінку в Instagram чи Tik-Tok.

Разом зі скаргою користувач, на дії якого вона була складена, може отримати контактні дані, адресу електронної пошти та ім'я власника авторських прав та більш детальну інформацію стосовно претензії. Таким чином, такий користувач може не лише зв'язатися із заявником, але й подати зустрічну скаргу, для з'ясування обставин та відстоювання своїх інтересів. 


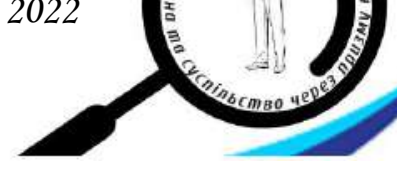

Оскільки дії відбуваються в рамках віртуального соціуму, то й санкції за порушення теж зазвичай віртуальні. Захисту прав інтелектуальної власності в соціальних мережах в судовому порядку не варто швидко чекати. Це ускладнюється декількома факторами, основні з яких - складність доказування та розслідування. Досить важко встановити реальну особу в соціальній мережі. Це стосується не лише порушників, але й авторів, які досить часто працюють під псевдонімами. Це ускладнює процес встановлення особистості, зокрема змушує звернутися до адміністрації соціальної мережі для отримання підтвердження приналежності автора до IP-адреси, 3 якої відбувалися публікації. Варто звернути увагу на можливість використання цифрового підпису, який дозволить ідентифікацію автора та можливість занесення твору до загальної бази.

Важливо зазначити, що соціальні мережі не несуть пряму відповідальність за контент, який там розміщено. Проте, в кожній спільноті існують певні Правила користувача, які мають на меті захистити авторські права користувачів.

Висновки. Як підсумок зазначимо, що інтелектуальна власність в соціальних мережах має охоронятися не лише Правилами користувача, але й більш досконалими законодавчими документами. Це має удосконалити систему розв’язання спорів у сфері інтелектуальної власності на законодавчому рівні. Це сприятиме зменшенню правопорушень в даній сфері.

\section{Лimepamypa:}

1. Про авторське право і суміжні права Закон України від 23.12.1993 № 3792-XII.

2. Ben Long. Watermarking Makes. Impression on Photos. MacWeek. Oct. 21, 1996. P. 16.

3. David Voss. Stop That Copy. Wired, 1994. P. 34.

4. TikTok surpassed Facebook, Instagram, Snapchat \& YouTube in downloads last month. TechCrunch (en-US).

5. Про авторське право і суміжні права Закон України від 23.12.1993 № 3792-XII.

6. Про деякі питання практики застосування господарськими судами законодавства про інформацію: Інформаційний лист Вищого господарського суду України 28.03.2007 р. № 01-8/184. URL: http://zakon2.rada.gov.ua/laws/show/v_184600-07

7. Умови надання послуг Facebook: m.facebook.com/legal/terms?locale=uk_UA.

\section{References:}

1. Zakon Ukrainy "Pro avtorske pravo i sumizhni prava" [The Law of Ukraine "On Copyright and Related Rights"]. (n.d.). zakon.rada.gov.ua. Retrieved from https://zakon.rada.gov.ua/laws/show/3792-12 [in Ukrainian]. [in Ukrainian].

2. Ben Long. Watermarking Makes. Impression on Photos. MacWeek. Oct. 21, 1996. P. 16.

3. David Voss. Stop That Copy. Wired, 1994. P. 34.

4. TikTok surpassed Facebook, Instagram, Snapchat \& YouTube in downloads last month. TechCrunch (en-US).

5. Zakon Ukrainy "Pro avtorske pravo i sumizhni prava" [The Law of Ukraine "On Copyright and Related Rights"]. (n.d.). zakon.rada.gov.ua. Retrieved from https://zakon.rada.gov.ua/laws/show/3792-12 [in Ukrainian]. [in Ukrainian]. 
6. Informatsiinyi lyst Vyshchoho hospodarskoho sudu Ukrainy "Pro deiaki pytannia praktyky zastosuvannia hospodarskymy sudamy zakonodavstva pro informatsiiu" [Information letter of the Supreme Commercial Court of Ukraine "On some issues of the practice of application of information legislation by commercial courts"]. (n.d.). zakon.rada.gov.ua. Retrieved from http://zakon2.rada.gov.ua/laws/show/v_184600-07 [in Ukrainian].

7. Umovi nadannja poslug Facebook [Terms of Facebook]. m.facebook.com . Retrieved from m.facebook.com/legal/terms?locale=uk_UA [in Ukrainian]. 